ISSN 2598-3180 (Online)

JOURNAL OF MIDWIFERY

Re se arch a n d P r a cice

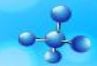

\title{
Belief Model (Hbm) of Via on Childbearing Women in Lubuk Buaya Primary Health Centre in 2017
}

\author{
Harridhil Silmi, Andi Friadi, Lisma Evareny \\ Bachelor Of Midwifery Program FK-UNAND, Jln Niaga No.56 Padang City, 25127, Indonesia \\ Bachelor Of Midwifery Program FK-UNAND, Jln Niaga No.56 Padang City, 25127, Indonesia \\ Bachelor Of Midwifery Program FK-UNAND, Jln Niaga No.56 Padang City, 25127, Indonesia
}

\begin{tabular}{l}
\hline SUBMISSION TRACK \\
\hline Recieved: Mei 172017 \\
Final Revision: Agustus 18, 2017 \\
Available Online: Nopember 24, 2017 \\
KEYWORD \\
\hline VIA, Perception, Health Beliefs Model \\
KORESPONDENSI \\
\hline
\end{tabular}

Phone: 075120120

E-mail:

\begin{abstract}
A B S T T R A C T
Cervical Cancer is the cancer with the second highest rate in Indonesian women and Awareness of childbearing women to Visual Inspection with Acetic Acid (VIA) is still low so often cause death in women. This study aims to determine the Health Beliefs Model (HBM) of VIA on childbearing women in Lubuk Buaya primary health centre 2017.

This study was an analytic observational study with cross sectional design, conducted from August - Sept 2017 took 98 respondents as the sample. Data were collected by using questionnaire. Data analysis was performed by using univariate and bivariate.

The results showed that there was a significant relationship between education $(\mathrm{p}=0,001)$, perceived susceptibility $(\mathrm{p}=0,000)$, perceived seriousness $(\mathrm{p}=0,000)$, health motivation $(\mathrm{p}=0,000)$, perceived benefits $(\mathrm{p}=0,000)$, and perceived barriers $(\mathrm{p}=0,000)$, with action cervical cancer early detection with VIA methods.

There is a relationship between education, perceived susceptibility, perceived seriousness, health motivation perceived benefits, and perceived barriers to early detection of cervical cancer action with VIA methods on childbearing women in Padang Pasir primary health centre 2017. Suggested to Lubuk Buaya primary health centre to increase further dissemination and health promotion of cervical cancer early detection with VIA method through counseling about the importance of early detection with VIA method.
\end{abstract}

\section{INTRODUCTION}

Cervical cancer is a disease in which malignant (cancer) cells desease starts in the cells lining the cervix, the lower part of the uterus (womb) (ACS, 2016). The main cause of cervical cancer is infection of persistent or chronic infection of one or more types of HPV which is 
oncogenic and transmitted through sexual intercourse (the WHO, 2014).

According to GLOBOCAN (IARC) 2012, cervical cancer ranks the province from the rest of cancer in women in the world. In the year 2012 , is estimated to be about 528,000 new cases of cervical cancer and cervical cancer deaths 266,000 . Nearly $87 \%$ of these deaths occur in developing countries.

In Indonesia, based on the Basic Health Research (Riskesdas) in the year 2013, the prevalence of cancer in Indonesia is 1.4 per 1000 inhabitants. While cervical cancer is the cancer with the second highest prevalence in Indonesia amounted to 0.8 per 1,000 population or approximately 98,692 residents. The prevalence of cervical cancer in West Sumatera amounting to 0.9 per 1,000 inhabitants. From these data it looks that the the prevalence of cervical cancer in the province of West Sumatra more than the prevalence of cervical cancer in Indonesia prevalence (Kemmenkes RI, 2013).

According to the WHO (2006) the delay of women aware of cervical cancer increasing the number of morbidity and mortality of cervical cancer, cervical cancer is one of the most types of cancer is preventable and curable of all cancers. Cervical cancer shows no symptoms of pain at all in the stadium early. This is causing a lot of women feel no need to checked early on.

Cervical cancer can be prevented by detecting precancerous lesions early. By detecting early cancer, then the pre lesions can be immediately done handler and cancer can be prevented. The Government has been implementing a program of early detection of cervical cancer in controlling cervical cancer with the use of methods of IVA (Kemmenkes RI, 2015).

detection VIA method is an efficient and cost-effective method. According to WHO (2006), the sensitivity of VIA is $77 \%$ (range 56$94 \%$ ) and specificity is $86 \%$ (between $74-94 \%$ ). VIA screening has shown a sensitivity close to Cytology examination standard (WHO, 2002).

According to WHO (2004), the coverage of cervical cancer early detection program at least $80 \%$ can decrease the number of cervical cancer morbidity and mortality significantly. While the Indonesia women's awareness to do early detection is still very low by coverage of the early detection of less than 5\% (Herman, 2014).
So does the awareness of women in the city of Padang in 2015 only amounted to $1.85 \%$. Of all the primary health centers that are located in the city of Padang, Lubuk Buaya primary health centre with the amount of 30-50 nth yearold childbearing women that is of 14,546 people. The scope of early detection methods of VIA in the year 2015 only amounted to $1.52 \%$ of the total childbearing women in the region of that primary Health Center (DKK, 2016).

Based on the preliminary studies in Lubuk Buaya primary health centre performed by researchers, through interviews with VIA program holder that factors that become barriers to the women don't do early detection of cervical cancer is a lack of the less education, knowledge or the lack of information about cancer and dininya detection, so it appears the anxiety, or embarrassed when the results are positive and choose to avoid it.

Based on studies conducted by Mutyaba et al. (2006) in Uganda, the individual's reason for not doing screening is: do not feel at risk, lack of symptoms, indifference, fear of vaginal examinations, lack of interest, the test is not fun and yet at the age that are at risk as well as $25 \%$ of female respondents only received vaginal examination with attendant females.

Oktaviana (2015) stated that there was a relationship between the perceived seriousness, the perceived susceptibility, the perceived benefits and perceived barriers with screening action of VIA.

From the explanation above seen that perception has a large role in shaping the behavior of one's health. People with high perceived seriousness, perceived susceptibility perceived benefit, and the low of perceived barriers will perform a precautionary measure against the disease. This is in accordance with the theory of Health Beliefs Model (HBM).

According to Taylor et al. (1999) States that there is a relationship between Health Belief with the participation of women in a cervical cancer early detection program based on the theory of the HBM. HBM was first introduced by Hochbaum et al. in 1950-60s to find why people do not want to participate in wellness with early detection of proram 4 main concepts on HBM i.e. perceived susceptibility, perceived seriousness, perceived benefits and the perceived barrier. The four main HBM perception modified by other variables, such as culture, level of 
education, previous experience, ability and motivation. (Edberg, 2007).

According to Cetisli et al. (2016) in addition to the health belief about cervical cancer, actions of VIA was also influenced by individual characteristics: age, education, Educaemployment, a source of information and a tion history of gynecological cancer IVA in the family.

The expected goal is to know the Health Belief Model (HBM) IVA on the childbearing woman in the working area Lubuk Buaya Primary Health Center of the year 2017.

\section{METHODS}

This study was an analytic observational study with cross sectional design, conducted in Lubuk Buaya Primary Health Center Padang city from August-September 2017. Population and sample the study are all Childbearing women who were married and aged 30-50 years as much as 98 people. The collection of data by means of questionnaires and observation. Questionnaires that researchers use in the research of adapting existing questionnaire Champion HBM (CHBM) Scales on the research of Guvenc et al. Data analysis was performed by using univariate and bivariate.

Sample the study are all Childbearing women who were married and aged 30-50 years as much as 98 people.

\section{RESULT}

\section{Respondent Characteristics}

Table 1. Frequency distribution of Action Cervical Cancer Early Detection With VIA Methods on Childbearing Woman in working area of Lubuk Buaya Primary Health Center 2017

\begin{tabular}{ccc}
\hline VIA actions & $\begin{array}{c}\text { Frequency } \\
(\mathbf{n = 9 8})\end{array}$ & Percentage (\%) \\
\hline Ever & 49 & 50,0 \\
Never & 49 & 50,0 \\
\hline All & $\mathbf{9 8}$ & $\mathbf{1 0 0 , 0}$ \\
\hline
\end{tabular}

Based on table 1 above, it can be seen that the number of respondents who ever did a cervical cancer early detection methods the IVA is equal to the number of respondents who never did a cervical cancer early detection method of VIA.
Table 2. The relationship between Education and Action Cervical Cancer Early Detection With VIA Methods on Childbearing Woman

\begin{tabular}{|c|c|c|c|c|c|c|c|c|}
\hline \multirow[t]{3}{*}{$\begin{array}{l}\text { Educa- } \\
\text { tion }\end{array}$} & \multicolumn{4}{|c|}{$\begin{array}{c}\text { Action early detection } \\
\text { with VIA }\end{array}$} & \multirow{2}{*}{\multicolumn{2}{|c|}{ Total }} & \multirow{3}{*}{$\begin{array}{c}\text { OR } \\
(95 \% \\
\text { CI })\end{array}$} & \multirow{3}{*}{$\begin{array}{c}p \\
\text { va- } \\
\text { lue }\end{array}$} \\
\hline & \multicolumn{2}{|c|}{ Ever } & \multicolumn{2}{|c|}{ Never } & & & & \\
\hline & $\mathbf{f}$ & $\%$ & $\mathbf{f}$ & $\%$ & $\mathbf{f}$ & $\%$ & & \\
\hline High & 44 & 60,3 & 29 & 39,7 & 73 & 100 & 6,069 & 0,00 \\
\hline Low & 5 & 20,0 & 20 & 80,0 & 25 & 100 & $(2,0-$ & 1 \\
\hline All & 49 & 50,0 & 49 & 50,0 & 98 & 100 & $18,0)$ & \\
\hline
\end{tabular}

Based on table 2 above shows that the respondents ever do early detection of cervical cancer more IVA method on highly educated respondents $(60.3 \%)$ compared to the low educated respondents $(20.0 \%)$. Based on statistical tests obtained $\mathrm{p}$ value $<0.05(\mathrm{p}=$ 0.001 ), meaning that there is a relationship between education and action early detection of cervical cancer of VIA method on the childbearing woman in the working area of Lubuk Buaya Primary Health Center, Padang City Year 2017.

Table 3. The relationship between Perceived Susceptibility and Action Cervical Cancer Early Detection With VIA Methods on Childbearing Woman

\begin{tabular}{|c|c|c|c|c|c|c|c|c|}
\hline \multirow{3}{*}{$\begin{array}{l}\text { Percei- } \\
\text { ved } \\
\text { Suscep- } \\
\text { tibility }\end{array}$} & \multicolumn{4}{|c|}{$\begin{array}{c}\text { Action early detection } \\
\text { with VIA }\end{array}$} & \multirow{2}{*}{\multicolumn{2}{|c|}{ Total }} & \multirow{3}{*}{$\begin{array}{c}\text { OR } \\
(95 \% \\
\text { CI })\end{array}$} & \multirow{3}{*}{$\begin{array}{c}p \\
\text { valu } \\
e\end{array}$} \\
\hline & \multicolumn{2}{|c|}{ Ever } & \multicolumn{2}{|c|}{ Never } & & & & \\
\hline & $\mathbf{f}$ & $\%$ & $\mathbf{f}$ & $\%$ & $\mathbf{f}$ & $\%$ & & \\
\hline High & 39 & 67,2 & 19 & 32,8 & 58 & 100 & 6,158 & 0,00 \\
\hline Low & 10 & 25,0 & 30 & 75,0 & 40 & 100 & $(2,5-$ & 0 \\
\hline All & 49 & 50,0 & 49 & 50,0 & 98 & 100 & $15,2)$ & \\
\hline
\end{tabular}

Based on table 3 above shows that respondents who ever do early detection of cervical cancer IVA method more on the respondent with the Perceived Susceptibility is high $(67.2 \%)$ compared to respondents with the low Perceived Susceptibility (25.0\%). Based on statistical tests obtained $\mathrm{p}$ value $<0.05(\mathrm{p}=$ 0.000 ), meaning that there is a relationship between Perceived Susceptibility and action early detection of cervical cancer of VIA method on the childbearing woman in the working area of Lubuk Buaya Primary Health Center, Padang City Year 2017. 
Table 4. The relationship between Perceived Seriousness and Action Cervical Cancer Early Detection With VIA Methods on Childbearing Woman

\begin{tabular}{cccccccc}
\hline $\begin{array}{c}\text { Perceived } \\
\text { Seriousne } \\
\text { ss }\end{array}$ & \multicolumn{3}{c}{$\begin{array}{c}\text { Action early detection } \\
\text { with VIA }\end{array}$} & Total & \multirow{2}{p}{$\begin{array}{c}\boldsymbol{p} \\
\text { value }\end{array}$} \\
\cline { 2 - 6 } & \multicolumn{2}{c}{ Ever } & \multicolumn{2}{c}{ Never } & & \\
\cline { 2 - 6 } & $\mathbf{f}$ & $\%$ & f & \% & f & \% & \\
\hline High & 49 & 79,0 & 13 & 21,0 & 62 & 100 & 0,000 \\
Low & 0 & 0,0 & 36 & 100,0 & 36 & 100 & \\
All & 49 & 50,0 & 49 & 50,0 & 98 & 100 & \\
\hline
\end{tabular}

Based on table 4 above shows that respondents who ever do early detection of cervical cancer more IVA method on the respondent with the Perceived Susceptibility is high $(79.0 \%)$ compared to respondents with the Perceived Susceptibility low $(0.0 \%)$. Based on statistical tests obtained $\mathrm{p}$ value $<0.05(\mathrm{p}=$ 0.000 ), meaning that there is a relationship between Perceived Susceptibility and action early detection of cervical cancer of VIA method on the childbearing woman in the working area of Lubuk Buaya Primary Health Center, Padang City Year 2017.

Table 5. The relationship between Health Motivation and Action Cervical Cancer Early Detection With VIA Methods on Childbearing Woman

\begin{tabular}{cccccccc}
\hline $\begin{array}{c}\text { Health } \\
\text { Motivatio } \\
\text { n }\end{array}$ & \multicolumn{4}{c}{$\begin{array}{c}\text { Action early detection } \\
\text { with VIA }\end{array}$} & Total & \multirow{p}{p}{$\begin{array}{c}\boldsymbol{p} \\
\text { value }\end{array}$} \\
\cline { 2 - 5 } & \multicolumn{2}{c}{ Ever } & \multicolumn{2}{c}{ Never } & & \\
\cline { 2 - 6 } & F & \% & f & \% & f & \% & \\
\hline High & 49 & 96,1 & 2 & 3,9 & 51 & 100 & 0,000 \\
Low & 0 & 0,0 & 47 & 100,0 & 47 & 100 & \\
All & 49 & 50,0 & 49 & 50,0 & 98 & 100 & \\
\hline
\end{tabular}

Based on table 5 above shows that respondents who ever do early detection of cervical cancer more IVA method on the respondent with the Health Motivation is high (96.1\%) compared to respondents with the Health Motivation low (0.0\%). Based on statistical tests obtained $\mathrm{p}$ value $<0.05(\mathrm{p}=$ 0.000 ), meaning that there is a relationship between Health Motivation and action early detection of cervical cancer of VIA method on the childbearing woman in the working area of Lubuk Buaya Primary Health Center, Padang City Year 2017.
Table 6. The relationship between Perceived Benefit and Action Cervical Cancer Early Detection With VIA Methods on Childbearing Woman

\begin{tabular}{|c|c|c|c|c|c|c|c|c|}
\hline \multirow[t]{3}{*}{$\begin{array}{l}\text { Perceived } \\
\text { Benefit }\end{array}$} & \multicolumn{4}{|c|}{$\begin{array}{c}\text { Action early detection } \\
\text { with VIA }\end{array}$} & \multirow{2}{*}{\multicolumn{2}{|c|}{ Total }} & \multirow{3}{*}{$\begin{array}{c}\text { OR } \\
\text { (95\% } \\
\text { CI) }\end{array}$} & \multirow{3}{*}{$\begin{array}{c}p \\
\text { valu } \\
e\end{array}$} \\
\hline & \multicolumn{2}{|c|}{ Ever } & \multicolumn{2}{|c|}{ Never } & & & & \\
\hline & $\mathbf{f}$ & $\%$ & $\mathbf{f}$ & $\%$ & f & $\%$ & & \\
\hline High & 44 & 72,1 & 17 & 27,9 & 61 & 100 & 16,565 & 0,00 \\
\hline Low & 5 & 13,5 & 32 & 86,5 & 37 & 100 & $(5,5-$ & 0 \\
\hline All & 49 & 50,0 & 49 & 50,0 & 98 & 100 & $49,6)$ & \\
\hline
\end{tabular}

Based on table 6 above shows that respondents who ever do early detection of cervical cancer more IVA method on the respondent with the Perceived Benefit is high (72.1\%) compared to respondents with the Perceived Benefit low (13.5\%). Based on statistical tests obtained $\mathrm{p}$ value $<0.05(\mathrm{p}=$ 0.000 ), meaning that there is a relationship between Perceived Benefit and action early detection of cervical cancer of VIA method on the childbearing woman in the working area of Lubuk Buaya Primary Health Center, Padang City Year 2017.

Table 7. The relationship between Perceived Barrier and Action Cervical Cancer Early Detection With VIA Methods on Childbearing Woman

\begin{tabular}{|c|c|c|c|c|c|c|c|c|}
\hline \multirow[t]{3}{*}{$\begin{array}{l}\text { Perceived } \\
\text { Barrier }\end{array}$} & \multicolumn{4}{|c|}{$\begin{array}{c}\text { Action early detection } \\
\text { with VIA }\end{array}$} & \multirow{2}{*}{\multicolumn{2}{|c|}{ Total }} & \multirow{3}{*}{$\begin{array}{c}\text { OR } \\
(95 \% \\
\text { CI })\end{array}$} & \multirow{3}{*}{$\begin{array}{c}p \\
\text { valu } \\
e\end{array}$} \\
\hline & \multicolumn{2}{|c|}{ Ever } & \multicolumn{2}{|c|}{ Never } & & & & \\
\hline & $\mathbf{F}$ & $\%$ & f & $\%$ & $\mathbf{f}$ & $\%$ & & \\
\hline Low & 48 & 81,4 & 11 & 18,6 & 59 & 100 & 0,006 & 0,00 \\
\hline High & 1 & 2,6 & 38 & 97,4 & 39 & 100 & $(0-0,1)$ & 0 \\
\hline All & 49 & 50,0 & 49 & 50,0 & 98 & 100 & & \\
\hline
\end{tabular}

Based on table 7 above shows that respondents who never do early detection of cervical cancer more IVA method on the respondent with the perceived barrier is low (81.4\%) compared to respondents with the perceived barrier high (2.6\%). Based on statistical tests obtained $\mathrm{p}$ value $<0.05(\mathrm{p}=$ 0.000 ), meaning that there is a relationship between perceived barrier and action early detection of cervical cancer of VIA method on the childbearing woman in the working area of Lubuk Buaya Primary Health Center, Padang City Year 2017. 


\section{DISCUSSION}

In this study, the number of respondents that do early detection of cervical cancer VIA method equals the number of respondents who never did a cervical cancer early detection method of VIA $(n=98)$. In this study the majority of the respondents had a high school-level education that is as much as 65 respondents $(66.3 \%)$. Education has a great influence towards an information and knowledge. The higher education of a person, the more receptive to information so that the more knowledge also owned (Hidayat, 2008).

There are two final education group in this study respondents, i.e. higher education (>junior high school) and the low education ( $\leq$ junior high school). The results of this research show from 98 the respondent as much as 73 $(74.5 \%)$ are highly educated and as many as 25 $(25.5 \%)$ of the low educated.

The results showed that respondents who ever do early detection of cervical cancer VIA method more on highly educated respondents $(60.3 \%)$ than the low educated respondents $(20.0 \%)$. Based on statistical tests obtained a value of $0.001 \mathrm{p}=$ indicating that there is a significant relationship between education with early detection of cervical cancer action method of the VIA. The respondents are highly educated, will increase the chances for action early detection of cervical cancer by as much as 6.1 times the VIA method compared to the low educated respondents (OR 6.1 (95\% CI: 2.0-18.0)).

The results of this research in line with the results of the research Masturoh (2016) and Karabulutlu (2013) where there is a significant relationship with the behavior of the childbearing women in conducting an examination of cervical cancer with an VIA. The higher the level of education a person allows one to do early detection of cervical cancer.

Based on the results of the study, noted that 98 people from the ditetiliti, the percentage of respondents respondents with high Perceived Susceptibility was $59.2 \%$ and respondents with low Perceived Susceptibility is $40.8 \%$. More than most of the respondents have had a high Susceptibility y against cervical cancer. It is clear that the respondents with high individual Perceived Susceptibility far more than respondents with Perceived Susceptibility is low. The results of this study are in line with the results of research conducted by Baskaran et al. (2013) that respondents with a high perception of individual vulnerability is more (71.8\%) compared with the perception of vulnerability of individuals of low and medium.

There are 3 questions about the vulnerability of a given individual, and of these 3 questions 51 respondents agree that are at high risk for severe cervical cancer in the next few years. This means that the respondents have a high Perceived Susceptibility against cervical cancer because it feels at risk. This is in line with the results of previous studies conducted by Saslow et al. (2002) that the individual who believes himself to have had severe risks for cervical cancer tends to be a precautionary measure. Individuals who have the perception that the risk does not have to have in mind that cervical cancer is one of the reasons for not doing the early detection of cervical cancer (Mutyaba et al, 2006).

The results showed that respondents who ever do early detection of cervical cancer VIA method more on the respondent with the perception of individual vulnerability is high $(67.2 \%)$ than respondents with the perception of individual vulnerability is low (25.0\%). Based on statistical tests obtained the value of $p=0.000$ which indicates that there is a significant relationship between the perception of vulnerability of individuals with early detection of cervical cancer action method of the IVA. Respondents with the perception of Perceived Susceptibility is high, will increase the chances for action early detection of cervical cancer as much as 6.2 times the VIA method compared with respondents ' Perceived Susceptibility is low (OR 6.2 (95\% CI: 2.5-15.2)).

The results of this study support the research of the Oktaviana (2015) that there is a significant relationship between the perception of vulnerability by performing screening VIA. This result is also in accordance with the theory of HBM by Rosenstock (1988) that the Perceived Susceptibility have positive relationship towards the health behavior. The higher Perceived Susceptibility, the higher chances of doing the behavior of prevention of the disease.

Based on the results of the study, noted that 98 people from the research, the percentage of respondents respondents with the perception of the seriousness of the disease is high and $63.3 \%$ of the respondents with low perception of the seriousness of the disease is $36.7 \%$. Most of 
the respondents have had the seriousness of the disease is high against cervical cancer. It is clear that the respondents with the perception of the seriousness of the disease is high much more than respondents with the perception of individual vulnerability is low. The results of this study are in line with the results of research conducted by Oktaviana (2015) that respondents with a high perception of individual vulnerability is more $(57.1 \%)$ compared with the perception of individual vulnerability is low.

There were 7 questions about the seriousness of the disease that is given, and the questions of 791 respondents agreed that the Issue would have experienced a related disease cervical cancer will last long. This means that the respondents have the perception of the seriousness of the disease is high against cervical cancer will be experienced because of the problems will last long. The results of this study are in line with the results of research conducted by Sauvageau et al. (2007) that $93 \%$ of women thought that cervical cancer has serious consequences.

The results showed that respondents who ever do early detection of cervical cancer VIA method more on the respondent with the perception of the seriousness of the disease is high $(79.0 \%)$ than respondents with the perception of the seriousness of the disease is low $(0.0 \%)$. Based on statistical tests obtained the value of $p=0.000$ which indicates that there is a significant relationship between the perception of the seriousness of the disease with early detection of cervical cancer action method of the VIA.

The results of this study support the research of Ma et al. (2013) that there is a significant relationship between the perception of the seriousness of the disease by performing acts of the early detection of cervical cancer. This result is also in accordance with the theory of HBM by Rosenstock (1988) that the perception of the seriousness of the disease have positive relationship towards the health behavior. The higher a person's perception of the seriousness of the disease, the higher chances of doing the behavior of the prevention of diseases.

Based on the results of the study, noted that 98 people from the ditetiliti, the percentage of respondents respondents with high health motivation was $52.0 \%$ and respondents with low health motivation was $48.0 \%$. The majority of respondents already have high health motivation against cervical cancer. It is clear that the respondents with high health motivation perception far more than respondents with low motivation of health.

There were 7 questions about the motivation of health care provided, and of the 7 questions Note that all respondents have the motivation of health that it is important to undertake activities that will bring a good effect for health as well as most large respondents want to detect health problems earlier.

The results of research conducted by Bukirwa et al. Bukirwa et al. (2015) suggests that the motivation to do early detection of cervical cancer is the need to get the examination, diagnosis and comprehensive tatalaksana to obtain health either. But the motivation is hindered by the wrong perception about early detection of cervical cancer. childbearing woman feel that will feel the pain, long queuing at health facilities, has no cost, privacy concerns and forgot to come to health facilities.

The results showed that respondents who ever do early detection of cervical cancer VIA method more on respondents with high health motivation $(96.1 \%)$ than respondents with low health motivation $(0.0 \%)$. Based on statistical tests obtained the value of $p=0.000$ which indicates that there is a significant relationship between health motivation with the early detection of cervical cancer action method of the VIA.

The results of this study support the research of Hoque et al. (2014) that there is a significant relationship between health motivation to do a screening VIA. This result is also in accordance with the theory of HBM by Rosenstock (1988) that the motivation of health has positive relationship towards the health behavior. The higher the motivation of a person's health, the higher chances of doing the behavior of prevention of the disease.

The results of this study showed that 98 people from the research, the percentage of respondents respondents with higher perceived benefit is $62.2 \%$ and respondents with low perceived benefit was $37.8 \%$. Most of the respondents have had high the perceived benefit against cervical cancer early detection method of VIA. It is clear that respondents with higher perceived benefit far more than respondents with low perceived benefit. The results of this study are in line with the results of research conducted by Baskaran et al. (2013) that respondents with 
higher perceived benefit more than perceived benefit of a low. Other studies conducted by Ibekwel et al. (2010) also showed that respondents that respondents with higher perceived benefit more (52.2\%) compared with the perception of a low benefit.

There are 4 questions about the perception of benefits provided, and from 4 to these questions in mind that $68.4 \%$ of respondents agree that the test is the best way to VIA diagnosis of early cervical cancer, get treatment earlier and did the test with regular VIA will lower the risk of death from cervical cancer. This means that respondents already know precisely that early detection of cervical cancer VIA method can be useful for lowering the risk of cervical cancer. Ibekwel found that good childbearing women ever or never did the early detection of cervical cancer agree and strongly agree that it is important to do early detection of cervical cancer (Ibekwel, 2010). The main reason childbearing women ever or never did the early detection of cervical cancer in the study Ibekwel that important do early detection of cervical cancer is because it can find changes in the cervix before turning into cancer and the disease can be easily cured when found early. The reason for this is also appropriate with the findings in other studies (Agurto et al., 2004; Ibekwe1, 2010). The results showed that respondents who never do early detection of cervical cancer more VIA method on respondents with higher benefit perception $(72.1 \%)$ than respondents with low benefit perception $(13.5 \%)$. Based on statistical tests obtained the value of $p=0.000$ which indicates that there is a significant relationship between the perception of benefits with the early detection of cervical cancer action method of the VIA. Respondents with higher benefit perception, will increase the chances for action early detection of cervical cancer by as much as 16.6 times the VIA method than respondents with low benefit perception (OR 0.4 (95\% CI: 5.5 to 49.6)).

The results of this study support the research of Ma et al. (2013) that there is a significant relationship between the perception of the benefits by doing the action of the early detection of cervical cancer. This result is also in accordance with the theory of HBM by Rosenstock (1988) that the perception of the benefits of having a positive relationship towards the health behavior. The higher the perception of benefits a person is, the higher the chances are also doing nutrition prevention of the disease.

The results of this study showed that 98 people from the ditetiliti, the percentage of respondents respondents with low barriers of perception is $60.2 \%$ and respondents with high barriers of perception was $39.8 \%$. Most of the respondents have the perception of a high resistance against cervical cancer early detection method of VIA. It is clear that the respondents with high barriers of perception far more than respondents with low barriers of perception. The results of this study are in line with the results of research conducted by Oktaviana (2015) that respondents with high barriers of perception more than perceptions of the benefits of a low.

Based on the research conducted, it is known that the greatest barrier for the respondent to do early detection of cervical cancer is due to an VIA method prefer the examiner clerk-sex women $(91.8 \%)$. Have no time and no health facilities nearby with a large barrier open houses in this regard (98.0\%). Previous research shows that the childbearing women have the perception that the procedure for the early detection of cervical cancer and painful embarrassment because officers VIA -sex male has a coverage of the early detection of cervical cancer are low (Ackerson K, 2010; Abdullahi 2009). Fear of abnormal results are also reported as barriers in conducting early detection of cervical cancer in previous studies (Winkler et al., 2008, Were et al, 2011).

The results showed that respondents who ever do early detection of cervical cancer VIA method more on respondents with low barriers of perception $(81.4 \%)$ than respondents with high barriers of perception (2.6\%). Based on statistical tests obtained the value of $p=0.000$ which indicates that there is a significant relationship between the perception of barriers with the early detection of cervical cancer action method of the VIA. Respondents with low barriers of perception, will increase the chances for action early detection of cervical cancer as much as VIA method 0.0 times than respondents with low barriers of perception (OR $0.0(95 \% \mathrm{CI}$ : 0.0-0.1)).

The results of this study support the research of Baskaran et al. (2013) that there is a significant relationship between the perception of barriers by performing acts of the early detection of cervical cancer. This result is also in accordance with the theory of HBM by 
Rosenstock (1988) that the perception of barriers have positive relationship towards the health behavior. The higher a person's perception of barriers, the lower the chances are also doing the behaviour of prevention of diseases.

\section{CONCLUSSION}

1. There is relationship between Education and Action Cervical Cancer Early Detection With VIA Methods on Childbearing Woman in the working area of Lubuk Buaya Primary Health Center, Padang City Year 2017.

2. There is relationship between health belief model component (perceived susceptibility, perceived seriousnes, health motivation, perceived benefit and perceived Barriers) and Action Cervical Cancer Early Detection With VIA Methods on Childbearing Womanin the working area of Lubuk Buaya Primary Health Center, Padang City Year 2017.

\section{REFERENCES}

Abdullahi, A, Copping, J, Kessel, A, Luck, A \& Bonell, C 'Cervical screening: Perceptions and barriers to uptake among Somali women in Camden', Public Health, vol. 123, no. 10. 2009. pp. 680-685.

Ackerson, K 'Personal Influences That Affect Motivation in Pap Smear Testing Among African American Women', Journal of Obstetrics, Gynecologic \& Neonatal Nursing, vol. 39, no. 2. 2010. pp. 136-146.

American Cancer Society 2014, Cervical Cancer. Viewed 11 Mei 2017 <https://www.cancer.org/content/dam/CRC/PDF/Public/8599.00.pdf $>$.

Baskaran, P, Subramanian, P, Rahman, RA, Ping, WL, Taib, NAM, \& Rosli, R 'Perceived Susceptibility, and Cervical Cancer Screening Benefits and Barriers in Malaysian Women Visiting

Outpatient

Clinics' Asian Pac J Cancer Prev, vol. 14, no. 12. 2013. pp. 7693-7699.

Cetisli, NE, Top, ED \& Işık, G 'Cervical Cancer and Pap Smear Test Health Beliefs and HealthPromoting Lifestyle of Women in Turkey', International Journal of Caring Sciences, vol. 9, no. 2. 2016. pp. 630-639.

Departemen Kesehatan Republik Indonesia Pencegahan Kanker Leher Rahim dan Kanker Payudara, Jakarta. 2009. Glosarium Data dan Informasi Kesehatan, Pusat Data dan Informasi, Jakarta

Dinas Kesehatan Kota Padang Profil Kesehatan Kota Padang Tahun 2015, Padang. 2016.

Guvenc, G, Akyuz, A \& Ikel, AC 'Health Belief Model Scale for Cervical Cancer and Pap Smear Test: psychometric testing', Journal of Advanced Nursing, vol. 67, no. 2. 2011. pp. 428437.

Herman Kesadaran untuk deteksi dini kanker serviks masih rendah, viewed 4 Desember 2016, http://yayasankankerindonesia.org/2014/kesadaran-untuk-deteksi-dini-kanker-serviksmasih-rendah/2014,

Hidayat, AA Pengantar Ilmu Keperawatan Anak 1, Jakarta. Salemba Medika. 2008. 
Hoque ME, Ghuman, S, Coopoosmay, R \& Hal, GV 'Cervical Cancer Screening among University Students inSouth Africa: A Theory Based Study', Plos ONE, vol. 9, no. 11. 2014.

Hoque, ME, Ibekwe, CM \& Ntuli-Ngcobo, B 'Screening and Perceived Severity of Cervical Cancer among Women Attending Mahalapye District Hospital, Botswana', Asian Pacific Journal of Cancer Prevention, Vol. 10. 2009. pp. 1095-1100.

Ibekwe, CM, Hoque, ME \& Ntuli-Ngcobo, B 'Perceived Benefits of Cervical Cancer Screening among Women Attending Mahalapye District Hospital, Botswana', Asian Pacific Journal of Cancer Prevention, vol. 11, no. 4. 2010. pp. 1021-1027.

International Agency for Research on Cancer Globocan 2012 : Cancer Fact Sheet, IARC. 2013.

Janz, NK, Champion,VL \& Strecher, VJ 'Health behavior and health education : theory, research and practice', San Fransisco. Jossey-Bass. 2002.

Karabulutlu, O 'Evaluation of the Pap Smear Test Status of Turkish Women and Related Factors', Asian Pacific J Cancer Prev, vol. 14, no. 2. 2013. pp. 981-986.

Kementerian Kesehatan RI. Situasi Penyakit Kanker, Jakarta. Pusat Data dan Informasi. 2015.

Pedoman Teknis Pengendalian Kanker Payudara dan Kanker Leher Rahim, Jakarta. 2013a.

Laporan Nasional Riset Kesehatan Dasar, Jakarta. Badan Penelitian dan Pengembangan Kesehatan Dasar, 2013b,

Ma, GX, Gao, W, Fang, CY, Tan, Y, Feng, Z, Ge, S \& Nguyen, JA 'Health Beliefs Associated with Cervical Cancer Screening Among Vietnamese Americans', Journal of Women's Health, vol. 22, no. 3. 2013. pp. 276-288.

Masturoh, E 'Faktor-Faktor yang Mempengaruhi Wanita Usia Subur (WUS) dalam Melakukan Deteksi Dini Kanker Serviks Metode Inspeksi Visual Asam Asetat (IVA)', Semarang. Universitas Negeri Semarang. 2016.

McGee, P Cervical Cancer', Diversity and Equality in Health and Care, vol. 12, no. 2. 2015. 'pp. 7780.

Mutyaba, T, Mmiro, AM \& Weiderpass, E 'Knowledge, attitudes and practices on cervical cancer screening among the medical workers of Mulago Hospital, Uganda', BMC Medical Education, vol. 6, no. 13. 2006.

Natphopsuk, S, Settheetham-Ishida, W, Sinawat, S, Pientong, C, Yuenyao, P \& Ishida, T 'Risk Factors for Cervical Cancer in Northeastern Thailand: Detailed Analyses of Sexual and Smoking Behavior', Asian Pacific J Cancer Prev, vol. 13, no. 11. 2012. pp. 5489-5495.

Oktaviana, MN 2015, 'Hubungan antara Persepsi Kerentanan Individu, Keseriusan Penyakit, Manfaat dan Hambatan dengan Penggunaan Skrining Inspeksi Visual Asam Asetat pada Wanita Usia Subur', UNS, Surakarta

Parapat, FT 'Faktor-Faktor yang Berhubungan dengan Perilaku WUS dalam Deteksi Dini Kanker Leher Rahim Metode IVA di Wilayah Puskesmas Candiroto Kabupaten Temanggung'. 2016.

Rismawari, E 'Faktor-Faktor yang Berhubungan dengan Minat Keikutsertaan WUS dalam Metode IVA'. 2014. 
Rossenstock, I, 'The Health Beliefs Model and Preventive Health Behaviour', Health Education Monogr, pp. 354-386.

Saslow, D, Runowicz, CD, Solomon, D, Moscicki, AB, Smith, RA, Eyre, HJ \& Cohen, C 'American cancer society guideline for the early detection of cervical neoplasia and cancer', A Cancer Journal for Clinicians, vol. 52, no. 6. 2002. pp. 342-362.

Sauvageau, C, Duval, B, Gilca, V, Lavoie, F \& Ouakki, M 'Human papilloma virus vaccine and cervical cancer screening acceptability among adults in Quebec, Canada', BMC Public Health, vol. 7, no.304. 2007

Susanti, A 'Faktor-Faktor yang Berhubungan dengan Rendahnya Kunjungan Inspeksi Visual Asam Asetat (IVA) di Wilayah Kerja Puskesmas Halmahera Kecamatan Semarang Timur Tahun 2010'. 2011.

Taylor, VM, Schwartz, SM, Jackson, JC, Alan, K, Meredith, F, Yutaka, Y, Tu, SP \& Thompson, B 'Cervical cancer screening among Cambodian-American women', Cancer Epidemiol Biomarkers, vol. 8, no. 6. 1999. Pp. 541-546

Were, E, Nyaberi, Z \& Buziba, N 'Perceptions of risk and barriers to cervical cancer screening at Moi Teaching and Referral Hospital (MTRH), Eldoret, Kenya', African Health Sciences, vol. 11, no. 1.2011. pp. 58-64.

Winkler, J., A. Bingham, P. Coffey dan W.P. Handwerker. Women's participation in a cervical cancer screening program in northern Peru. Health Education Research 23 (1). 2008. 10-24

World Health Organization Cervical screening in developing countries: Report of a WHO consultation, WHO, Geneva. 2002

Progress in Reproductive Health Research, Geneva. WHO. 2004.

Comprehensive Cervical Cancer Control: a Guide to Essential Practice, Edisi Pertama, Geneva. WHO. 2006.

Prevention of cervical cancer through screening using visual inspection with acetic acid (VIA) and treatment with cryotherapy. A demonstration project in six African countries: Malawi, Madagascar, Nigeria, Uganda, the United Republic of Tanzania, and Zambia, Geneva. WHO. 2012.

Comprehensive Cervical Cancer Control: a Guide to Essential Practice, Edisi kedua, Geneva. WHO. 2014.

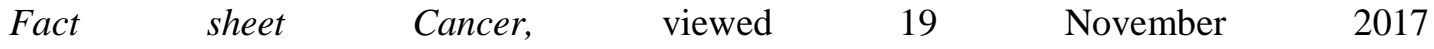
<http://www.who.int/mediacentre/factsheets/fs380/en/>. 2016.

Inequalities in Women's and Girls' Health Opportunities and Outcomes: A Report from Sub-Saharan Africa, viewed 11 februari 2017, <http://www.who.int/pmnch/media/news/2017/inequalities_women/en>. 2017.

Yulizawati 'Faktor-Faktor yang Berhubungan dengan Perilaku WUS dalam Deteksi Dini Kanker Leher Rahim Metode IVA di Wilayah Puskesmas Prembun Kabupaten Kebumen Tahun 2012', Jakarta. Universitas Indonesia. 2012.

Zitkute, V \& Bumbuliene, Z 'Risk Factors Affecting HPV Infection, Persistence and Lesion Progression in Women and Men', Clinical Research in Infectious Diseases, vol. 3. No. 2. 2016. pp. 1026. 